\title{
ANALISIS PERHITUNGAN COST PENGELOLAAN SAMPAH (STUDI PADA BUMDES AMARTA)
}

\author{
Bobby Himawan \\ STIE Madani Balikpapan
}

\begin{abstract}
Abstrak
Penelitian ini bertujuan untuk menganalisis perbandingan metode full costing dan variable costing dalam perhitungan harga pokok produksi untuk menentukan harga jual produk pada BUMDes Amarta. Metode full costing adalah metode penentuan harga pokok produk yang memperhitungkan semua unsur biaya produksi yang terdiri dari biaya bahan baku, biaya tenaga kerja langsung dan biaya overhead pabrik, baik yang bersifat tetap maupun variabel. Sedangkan variable costing adalah metode penentuan harga pokok produk yang hanya memperhitungkan biaya produksi variabel yang terdiri dari biaya bahan baku, biaya tenaga kerja langsung, dan biaya overhead pabrik. Penelitian ini termasuk penelitian deskriptif. Data yang digunakan, data primer dan sekunder. Metode analisis yang digunakan metode deskriptif yaitu metode yang digunakan untuk menggambarkan atau menganalisis suatu hasil penelitian tetapi tidak digunakan untuk membuat kesimpulan yang lebih luas.

Hasil penelitian dan perhitungan ini menunjukkan adanya kelemahan dalam perhitungan harga pokok perusahaan. Berdasarkan perbandingan metode full costing dan variable costing dalam perhitungan harga pokok produksi pada perusahaan, metode full costing menunjukkan harga pokok yang jauh lebih tinggi daripada metode variable costing, disebabkan karena dalam perhitungan harga pokok produksi pada metode full costing memasukkan semua akun biaya baik yang berjenis variabel maupun tetap. BUMDes Amarta sebaiknnya memasukkan akun-akun seperti biaya penyusutan mesin, biaya penyusutan gedung, biaya penyusutan kendaraan dan peralatan serta biaya asuransi dalam harga pokok produsi dan penentuan harga pokok produk menjadi lebih tepat.
\end{abstract}

Kata kunci: traditional costing, full costing, variable costing, harga pokok produksi, harga jual 


\section{PENDAHULUAN}

Desa merupakan agen pemerintah yang paling depan dalam melaksanakan pembangunan karena pembangunan di tingkat desa berkenaan langsung dengan masyarakat. Dalam mendorong pembangunan di tingkat desa, pemerintah memberikan kewenangan kepada pemerintah desa untuk mengelola daerahnya secara mandiri. Salah satunya adalah melalui lembaga ekonomi yang berada di tingkat desa, yakni Badan Usaha Milik Desa (BUMDes). Lembaga berbasis ekonomi ini menjadi salah satu program yang dijalankan desa sebagai sarana untuk meningkatkan Pendapatan Asli Desa (PADes). BUMDes berperan sebagai instrumen penguatan otonomi desa, maksudnya adalah untuk mendorong pemerintah desa. Sebagai instrumen kesejahteraan masyarakat, yakni dengan melibatkan masyarakat, diharapkan BUMDes akan mendorong kemajuan ekonomi dan mengurangi tingkat pengangguran di desa.

BUMDes merupakan badan usaha yang sesuai dengan mandat undangundang karena kepemilikannya berasal dari seluruh masyarakat desa yang bersangkutan. Setiap keputusan BUMDes harus sesuai dengan mekanisme persetujuan musyawarah desa (musdes). Variasi BUMDes terutama berbasis dari kekuatan desa itu sendiri, semisalnya pertanian, kerajinan, industri mikro (garmen), pariwisata, dan lain-lain. Keberadaan BUMDes dapat menjadi wadah masyarakat desa dalam meningkatkan kemakmuran dan perekonomian desa. Penelitian ini mengkaji BUMDes Amarta di Desa Pandowoharjo, Kabupaten Sleman yang berfokus pada bidang pengelolaan sampah, khususnya sampah-sampah yang dikelola menjadi pupuk organik (kompos) dan pupuk cair.

BUMDes Amarta berdiri pada 6 Juni 2016, yang berawal dari upaya pemecahan masalah Desa Pandowoharjo mengenai pengelolaan sampah. Pada awalnya organisasi masyarakat di Desa Pandowoharjo, Kabupaten Sleman yang memiliki unit usaha pengelolaan sampah "Pendowo Lestari" berhasil mendapatkan hibah peralatan pengelolaan sampah dari Dinas Pekerjaan Umum. Namun demikian, terdapat kendala usaha pengelolaan sampah, pengelolaannya tidak lancar. Dengan demikian, hibah peralatan pengelolaan sampah desa tersebut 
diserahkan ke Desa Pandowoharjo. Kemudian sesuai dengan hasil musyarawah desa, unit usaha pengelolaan sampah tersebut dijadikan sebagai unit BUMDes dan desa memberikan dana desa sebesar Rp 50 juta untuk memperbaiki peralatan yang rusak.

BUMDes Amarta berencana untuk menjadikan sampah organik sebagai bahan pembuatan pupuk organik. Usaha pembuatan pupuk organik menjadi salah satu unit usaha yang akan dikembangkan menjadi sumber pendapatan oleh BUMDes Amarta. BUMDes Amarta juga akan bergerak sebagai broker atau distributor potensi wisata desa dan UMKM yang ada di Desa Pandowoharjo. Dengan ini, tidak akan terjadi persaingan antara BUMDes Amarta dengan usahausaha lain yang telah lebih dahulu dijalankan oleh warga sekitar. BUMDes Amarta juga memiliki toko desa yang masih perlu dikembangkan dan berencana untuk memberikan paket kunjungan bagi BUMDes lain yang ingin belajar tentang cara menjalankan BUMDes.

UU No 6 Tahun 2014 tentang Desa menyebutkan bahwa Desa dapat membentuk BUMDes. Sesuai dengan UU tersebut, BUMDes Amarta lahir sebagai wujud hadirnya pemerintah desa ketika masyarakat mendapatkan masalah-masalah penyediaan layanan dasar yang belum dikelola penuh oleh masyarakat, dengan menggerakkan perekonomian desa untuk menyejahterakan warga dan masyarakat sekitar, serta memberikan akses ekonomi bagi masyarakat miskin BUMDes. mengelola aset desa sebagai instrumen kelembagaan desa untuk belajar bagi desa yang berinvestasi serta menggali dan mengembangkan potensi-potensi ekonomi yang ada sebagai sumber pendapatan asli desa (PAD).

Dengan adanya pengelolaan sampah menjadi pupuk, diperlukan perhitungan cost pengelolaan sampah yang baik untuk mengetahui penetapan harga jual dan unit cost yang bisa dicapai oleh BUMDes Amarta dan untuk mencapai pendapatan yang sesuai target. Akan tetapi BUMDes Amarta belum mempunyai metode perhitungan cost pengelolaan sampah yang dapat memprediksi sampai sejauh mana produksi pupuk ini akan berjalan lancar. Selain itu BUMDes Amarta belum bisa menentukan penggunaan standar akuntansi yang cocok. Berdasarkan 
latar belakang di atas, penelitian berjudul "Analisis Perhitungan Cost Pengelolaan Sampah dan Pelaporan Keuangan (Studi pada BUMDes Amarta)”.

\section{Pertanyaan Penelitian}

Berdasarkan latar belakang dan rumusan permasalahan yang telah dikemukakan di atas, maka pertanyaan penelitian adalah sebagai berikut.

1. Bagaimana perhitungan cost pengelolaan sampah di BUMDes Amarta saat ini?

2. Apa sajakah kelemahan perhitungan cost pengelolaan sampah BUMDes Amarta saat ini?

3. Apakah ada alternatif untuk perhitungan cost pengelolaan sampah yang lebih baik?

\section{Tujuan Penelitian}

Tujuan dari penelitian ini adalah:

1. Untuk menganalisis perhitungan cost pengelolaan sampah yang dilakukan BUMDes Amarta saat ini.

2. Untuk mengidentifikasi faktor-faktor kelemahan dalam perhitungan cost pengelolaan sampah di BUMDes Amarta.

3. Untuk menentukan perhitungan cost pengelolaan sampah yang lebih akurat.

\section{Manfaat Penelitian}

Manfaat penelitian ini, antara lain, adalah sebagai berikut:

1. Bagi BUMDes Amarta

Manfaat yang diperoleh bagi BUMDes Amarta adalah memperoleh hasil perhitungan pengelolaan sampah yang akurat dan dapat diterapkan untuk menentukan harga pokok penjualan pupuk/kg yang belum ada perhitungannya saat ini.

2. Bagi Penulis

Manfaat yang diperoleh adalah dapat memahami dan mengembangkan ilmu mengenai perhitungan cost pada pengelolaan sampah. 


\section{Kontribusi Penelitian}

Kontribusi Penelitian ini, antara lain adalah sebagai berikut:

1. Kontribusi Praktis

Bagi BUMDes Amarta, penelitian ini memberikan evaluasi harga jual yang telah ditetapkan sehingga mampu bersaing dalam persaingan bisnis pupuk, memberikan masukan mengenai perhitungan cost pengelolaan sampah yang baik, dan dapat menentukan harga jual yang lebih akurat.

2. Kontribusi Kebijakan

Bagi akademisi, penelitian ini dapat memberikan acuan tentang perhitungan cost pengelolaan sampah dengan metode traditional costing dalam kaitannya dengan penentuan unit cost pada BUMDes Amarta dan memperoleh pemahaman konsep metode cost produksi yang belum banyak diteliti.

\section{KERANGKA TEORI}

\section{Definisi Bank Sampah}

Bank sampah merupakan suatu proyek didirikan oleh komunitas yang bertujuan sebagai wadah sampah yang telah dipilah-pilah. Hasil dari sampah yang telah dipilah akan disetorkan ke tempat pembuatan kerajinan dari sampah atau ke tempat pengepul sampah. Bank sampah dikeloa menggunakan sistem seperti perbankan yang dilakukan oleh petugas sukarelawan dan warga berperan sebagai penyetor sampah dan mendapatkan buku tabungan seperti menabung di bank. Tujuan bank sampah adalah untuk membantu menangani pengolahan sampah di Indonesia dan menyadarkan masyarakat akan lingkungan serta merubah paradigma masyarakat mengenai sampah (Setyaningrum, 2015). 


\section{Definisi Cost}

Cost merupakan pengukur dan sekaligus bahan olah akuntansi. Istilah biaya, harga pokok, atau harga perolehan tidak tepat sebagai padan kata istilah cost. Biaya lebih merupakan wadah (objek) daripada pengukur atau bahan olah akuntansi dalam menghasilkan informasi kuantitatif. Cost juga tidak tepat kalau disebut sebagai harga perolehan (mestinya kos pemerolehan) karena harga pemerolehan hanya berlaku untuk menunjuk cost pada saat terjadinya (Suwardjono, 2014).

\section{Analisis Perilaku Biaya}

Proses produksi dan penjualan barang dan jasa memerlukan perencanaan dan pengendalian biaya. Hal ini dapat berjalan baik jika manajer dapat memahami secara menyeluruh mengenai hubungan antara biaya dengan aktivitas bersangkutan, yang sering disebut sebagai perilaku biaya. Menilai perilaku biaya dapat maksimal jika dilakukan pencatatan atas biaya yang digunakan dan sumber daya yang diperoleh.

Dalam hal ini Horngren (2008: 236) mengklasifikasikan pola perilaku biaya menjadi dua jenis, yaitu biaya variabel dan biaya tetap. Biaya variabel (variable cost) secara total berubah seiring dengan perubahan tingkat aktivitas atau volume yang terkait. Biaya tetap (fixed cost) tidak akan berubah secara total selama periode waktu tertentu, sekalipun terjadi perubahan besar atas tingkat aktivitas atau volume terkait. Klasifikasi ini berlaku jika biaya dikaitkan dengan suatu aktivitas tertentu atau periode waktu tertentu.

Berdasarkan pendapat para ahli tersebut, maka pola perilaku dapat diklasifikasikan menjadi biaya variabel dan biaya tetap. Biaya variabel merupakan biaya yang berubah sesuai dengan intensitas dari aktivitas. Dan biaya tetap merupakan biaya yang bersifat tetap pada waktu tertentu dan tidak bergantung pada intensitas dari aktivitas yang berlangsung.

\section{Unit Cost}

Unit cost adalah biaya total objek biaya tertentu dibagi jumlah denominator keluaran yang dihasilkannya. Untuk menghitung biaya per unit secara teliti perlu 
ditentukan satuan ukuran keluaran objek biaya tertentu hasil perhitungan biaya satuan dikenal dengan dua macam biaya yaitu (a) biaya satuan normatif, biaya yang berlaku sesuai dengan peraturan daerah (Perda); (b) biaya satuan aktual, suatu hasil perhitungan berdasarkan atas pengeluaran nyata untuk menghasilkan produk pada kurun waktu tertentu biaya satuan aktual ini dihitung dengan menggunakan formula $\mathrm{UC}=\mathrm{TC} / \mathrm{TO}($ Supriyono, 2007).

Unit cost adalah penghitungan yang didasarkan pada biaya-biaya yang dikeluarkan secara nyata dalam rangka pelayanan kepada masyarakat. struktur tarif yang dapat dipakai untuk mengatasi keterbatasan subsidi dan harga pasaran yang berlaku adalah dengan pendekatan unit cost. Biaya satuan sangat penting artinya karena merupakan salah satu dasar dalam menentukan tarif pelayanan disamping faktor kemampuan dan kemauan membayar dari masyarakat.

\section{Full Costing}

Terdapat beberapa metode dalam penentuan harga pokok. Menurut Mulyadi (1993) menyebutkan metode full costing merupakan salah satu metode penentuan harga pokok produksi, baik biaya produksi yang berperilaku variabel maupun tetap. Jika perusahaan menggunakan pendekatan full costing dalam penentuan harga pokok produksinya, full cost merupakan total biaya produksi (biaya bahan baku + biaya tenaga kerja langsung -biaya overhead pabrik variabel + biaya overhead pabrik tetap) ditambah dengan total biaya non produksi (biaya administrasi \& umum + biaya pemasaran).

Full cost dapat pula dihitung dengan menggunakan variable costing dalam perhitungan harga pokok produksinya. Variable costing merupakan salah satu metode penentuan harga pokok produksi, disamping full costing, yang membebankan hanya biaya produksi yang berperilaku variabel saja kepada produk. Jika perusahaan menggunakan pendekatan full costing dalam penentuan harga pokok produksinya, full cost merupakan total biaya variabel ditambah dengan total biaya tetap. 


\section{Variable Costing}

Dalam penghitungan harga pokok produk memperhitungkan biaya produksi variabel yang terdiri dari biaya bahan baku, biaya tenaga kerja langsung, dan biaya overhead pabrik. Jadi dalam penghitungannya terdiri dari unsur harga pokok produksi variabel (biaya bahan baku, biaya overhead pabrik variabel, biaya tenaga kerja langsung) ditambah dengan biaya non produksi variabel (biaya pemasaran variabel, biaya administrasi umum variabel), dan biaya tetap (biaya overhead tetap, biaya pemasaran tetap, biaya administrasi dan umum tetap).

\section{Sistem Biaya Tradisional}

Sistem biaya tradisional yang banyak digunakan perusahaan tidak dapat memperhitungkan biaya-biaya tidak langsung ke produk menggunakan dasar alokasi seperti jam tenaga kerja langsung atau jam mesin. Menurut Carter (2009:499-500): “Sistem biaya tradisional memiliki karakteristik khusus yaitu penggunaan ukuran yang berkaitan dengan volume atau ukuran tingkat unit secara eksklusif sebagai dasar untuk mengalokasikan overhead ke output. Untuk alasan tersebutlah maka sistem biaya tradisional disebut juga sistem berdasarkan unit (Unit Cost System)".

Dalam menghitung harga pokok produk dengan menggunakan sistem biaya tradisional, pembebanan biaya atas biaya tidak langsung dilakukan dengan menggunakan dasar pembebanan secara menyeluruh atau per departemen. Hal ini akan menimbulkan banyak masalah karena produk yang dihasilkan tidak dapat mencerminkan biaya yang sebenarnya diserap untuk menghasilkan produk tersebut. Sebagai akibatnya akan muncul produk perhitungan kos yang kurang saji (undercosted) dan produk perhitungan kos yang lebih saji (overcosted).

Dalam sistem secara tradisional dapat dilihat bahwa biaya-biaya yang terlibat biasanya hanya biaya langsung saja, yaitu biaya tenaga kerja dan biaya material. Namun seiring dengan berjalannya waktu biaya-biaya yang bisa digolongkan kedalam biaya langsung. Biaya-biaya tersebut seperti biaya reparasi, perawatan, utilitas, dan lain sebagainya. Sistem biaya akan membebankan biaya tidak langsung kepada basis alokasi yang tidak representatif. 
Menurut Carter (2009: 107), sistem biaya yang dialokasikan ke unit produksi dapat digolongkan menjadi dua macam, yaitu:

1. Biaya Aktual atau Historis

Dalam sistem biaya aktual atau historis, informasi biaya dikumpulkan pada saat biaya terjadi, tetapi penyajian hasilnya ditunda sampai semua operasi produksi untuk periode akuntansi tersebut telah selesai dilakukan atau dalam bisnis jasa, semua jasa untuk periode tersebut telah diserahkan.

2. Biaya standar

Dalam sistem biaya standar, produk-produk, operasi-operasi, dan prosesproses dihitung biayanya berdasarkan jumlah yang telah ditentukan sebelumnya dari sumber daya yang akan digunakan dan harga yang telah ditentukan sebelumnya dari sumber daya tersebut.

Alokasi biaya ke unit produksi bisa saja memasukkan seluruh biaya manufaktur atau hanya yang bersifat variabel, yaitu melalui full costing dan variable costing seperti yang telah disampaikan sebelumnya pada bagian

\section{METODOLOGI PENELITIAN}

\section{Desain Penelitian}

Desain Penelitian ini studi kasus yang menggunakan pendekatan kualitatif sebagaimana diungkapkan Creswell (2014, p. 14) sebagai berikut.

Studi kasus merupakan strategi penelitian di mana di dalamnya menyelidiki secara cermat suatu program, peristiwa, aktivitas, proses, atau sekelompok individu. Kasus-kasus dibatasi oleh waktu dan aktivitas, dan peneliti mengumpulkan informasi secara lengkap dengan menggunakan berbagai prosedur pengumpulan data berdasarkan waktu yang telat dtentukan.

Penelitian studi kasus (Yin, 2014) merupakan salah satu dari penelitian ilmu sosial. Peneliti memiliki sedikit kendali atau bahkan tidak memiliki kendali sama sekali terhadap peristiwa yang diteliti, dan studi berfokus pada fenomena yang kontemporer. 
Berdasarkan rumusan masalah dan pertanyaan penelitian yang diuraikan sebelumnya, maka penelitian ini menggunakan pendekatan kualitatif. Menurut Creswell (2015) penelitian ini dimulai dengan asumsi yang memengaruhi studi tentang permasalahan riset yang terkait dengan makna yang dikenakan oleh individu atau kelompok pada suatu permasalahan sosial. Penelitian ini menggunakan metode studi kasus untuk mengeksplorasi permasalahan penelitian.

\section{Teknik Pengumpulan Data}

Teknik pengumpulan data dalam penelitian ini dibagi menjadi 4 yaitu:

1) Studi Literatur

Studi Literatur dilaksanakan dengan mempelajari, membandingkan dan meringkas hasil penelitian terdahulu. Selain itu, akan dipelajari metode traditional costing untuk menghitung cost pengelolaan sampah di BUMDes Amarta, Desa Pandowoharjo, Kabupaten Sleman.

\section{2) Observasi}

Teknik pengumpulan data dengan pengamatan dan pencatatan suatu obyek dari fenomena yang diselidiki. Observasi dapat dilakukan sesaat ataupun mungkin dapat diulang. Observasi ini dilakukan secara informal sehingga mampu mengarahkan peneliti untuk mendapatkan informasi sebanyak mungkin informasi yang berkaitan dengan masalah penelitian. Observasi ini dilakukan di BUMDes Amarta, Desa Pandowoharjo, Kabupaten Sleman.

3) Dokumentasi

Dokumentasi merupakan catatan peristiwa yang sudah berlalu. Dokumen yang digunakan dalam penelitian ini berupa foto, gambar, serta data-data mengenai variabel penelitian yang akan diteliti. Cara pengumpulan data dengan menggunakan arsip atau dokumen-dokumen yang bersifat tulisan atau laporan keuangan dari BUMDes Amarta. Sementara itu, hasil penelitian dari observasi dan wawancara dapat dipercaya apabila didukung oleh dokumentasi penelitian.

4) Wawancara Mendalam

Wawancara yang akan dilakukan dalam penelitian ini merupakan wawancara semi terstruktur dengan berpedoman pada panduan. Wawancara 
mendalam bertujuan untuk mendapatkan wawasan pada isu tertentu (Hennink et al., 2011). Untuk memperoleh wawasan yang mendalam dari perspektif partisipan (perspektif emic), akan dilakukan wawancara semi terstruktur, akan dibangun hubungan dengan partisipan, akan diajukan pertanyaan secara terbuka, dan partisipan akan dimotivasi agar menceritakan pengalamannya.

\section{Teknik Analisis Data}

Analisis data yang dilakukan untuk mengetahui biaya yang sesungguhnya oleh BUMDes Amarta dalam mengelola sampah menjadi pupuk dengan metode traditional costing adalah sebagai berikut:

1. Menghitung cost pengelolaan sampah yang sesungguhnya dikeluarkan oleh BUMDes Amarta.

2. Menganalisis cost pengelolaan sampah tersebut.

Menurut Miles et al (2014) teknik analisis data dapat dilakukan dengan langkahlangkah sebagai berikut:

1. Data dari hasil wawancara yang cukup banyak kemudian akan direduksi. Reduksi data ini ialah merangkum, memilih hal-hal pokok, dan mencari tema serta polanya. Hal ini akan memberikan gambaran yang lebih jelas mengenai data yang dibutuhkan dalam penelitian.

2. Penyajian data bertujuan agar data terorganisir, tersusun dalam pola hubungan. Hal ini akan memudahkan untuk memahami apa yang terjadi dan menentukan rencana kerja selanjutnya.

Penarikan kesimpulan dan verifikasi yang dapat berupa deskripsi atau gambaran terhadap suatu obyek. Dengan demikian, hasil penelitian akan menjawab pertanyaan penelitian atas fenomena yang diteliti.

\section{Validitas dan Reliabilitas Data}

Dalam penelitian ini triangulasi yang dilakukan menurut Yin (2014) dalam pengujian validitas data, sebagai berikut: 
1. Triangulasi sumber pada penelitian ini dilakukan dengan mengumpulkan data dari beberapa sumber yaitu Direktur BUMDes Amarta, Sekretaris BUMDes Amarta, Bendahara BUMDEs Amarta dan Kepala Desa Pandowoharjo.

2. Triangulasi teknik dilakukan dengan menggunakan 3 metode pengambilan data, yaitu observasi partisipatif, dokumentasi, dan wawancara.

3. Member checking yang dilakukan setelah peneliti menyelesaikan olah data dan diberikan kepada pemberi data. Hal ini bertujuan untuk mengetahui kesesuaian data dan penafsiran data antara penliti dengan pemberi data.

Sementara itu, penelitian dikatakan reliabel jika orang lain dapat mengulangi atau mereplikasi proses penelitian tersebut akan menghasilkan kesimpulan yang sama (Sugiyono, 2016: 377). Dalam penelitian ini, untuk menjamin reliabilitas penelitian, maka peneliti melakukan pengecekan kembali hasil transkripsi dari wawancara untuk memastikan tidak ada yang missed atau hilang dan juga memastikan tidak ada kesalahan serta mengecek kode yang telah dibuat untuk mengurangi makna bias. Selain itu, peneliti juga melakukan dokumentasi prosedur penelitian, sehingga apabila peneliti berikutnya melakukan prosedur yang sama, maka akan didapatkan hasil penelitian yang sama.

\section{HASIL DAN PEMBAHASAN}

\section{Analisis Perhitungan Full Costing dan Variable Costing}

Metode ini adalah metode yang semua biaya yang timbul untuk memproduksi suatu barang ataupun jasa dibebankan secara penuh ke dalam harga jual dari produk/jasa tersebut. Hal ini menunjukkan bahwa semua, biaya baik variabel maupun tetap harus dapat diperhitungkan dengan pendapatan yang diperoleh dari penjualan produk/jasa. Pada analisis ini peneliti tidak menghitung perhitungan pada tahun 2016 dikarenakan data yang didapatkan kurang dan pada tahun 2016 BUMDes Amarta sedang berada dalam proses pembelajaran dan pengembangan. Berikut hasil perhitungan full costing dan variable costing pada tahun 2017 serta analisisnya. 
Tabel 1

Perhitungan Full Costing dan Variable Costing Tahun 2017

\begin{tabular}{|c|c|c|}
\hline \multicolumn{3}{|c|}{$\begin{array}{l}\text { BUMDes Amarta - Unit Pengelolaan Sampah } \\
\text { Full Costing dan Variable Costing }\end{array}$} \\
\hline Keterangan & Full Costing & $\begin{array}{l}\text { Variable } \\
\text { Costing }\end{array}$ \\
\hline \multicolumn{3}{|l|}{ Biaya Bahan Baku } \\
\hline Biaya Produksi & Rp8.364.000 & Rp8.364.000 \\
\hline \multicolumn{3}{|l|}{$\begin{array}{l}\text { Biaya Tenaga Kerja } \\
\text { Langsung }\end{array}$} \\
\hline $\begin{array}{l}\text { Biaya Tenaga } \\
\text { Operasional }\end{array}$ & Rp40.460.000 & Rp40.460.000 \\
\hline \multicolumn{3}{|l|}{$\begin{array}{l}\text { Biaya Overhead } \\
\text { Pabrik Variabel }\end{array}$} \\
\hline $\begin{array}{l}\text { Biaya Layanan } \\
\text { Pengambilan Sampah }\end{array}$ & Rp 21.741.115 & Rp21.741.115 \\
\hline Biaya Bongkar Muat & Rp3.955.000 & Rp3.955.000 \\
\hline Biaya Bahan Bakar & Rp768.000 & Rp.768.000 \\
\hline Biaya Listrik & Rp463.000 & Rp.463.000 \\
\hline $\begin{array}{l}\text { Biaya } \\
\text { Tranportasi/Angkut }\end{array}$ & Rp1.538.900 & Rp1.538.900 \\
\hline & Rp28.466.015 & Rp28.466.015 \\
\hline \multicolumn{3}{|l|}{$\begin{array}{l}\text { Biaya Overhead Pabrik } \\
\text { Tetap }\end{array}$} \\
\hline $\begin{array}{l}\text { Biaya penyusutan } \\
\text { kendaraan }\end{array}$ & Rp7.666.667 & \\
\hline $\begin{array}{l}\text { Biaya penyusutan mesin } \\
\text { dan peralatan }\end{array}$ & Rp4.681.250 & \\
\hline $\begin{array}{l}\text { Biaya penyusutan } \\
\text { bangunan dan kantor }\end{array}$ & Rp2.334.812 & \\
\hline $\begin{array}{l}\text { Biaya Pemeliharaan } \\
\text { Bangunan, Mesin, } \\
\text { Peralatan }\end{array}$ & Rp303.000 & \\
\hline & Rp14.985.729 & \\
\hline Harga Pokok Produksi & Rp92.275.744 & Rp77.290.015 \\
\hline \multicolumn{3}{|l|}{ Penjualan Pupuk } \\
\hline Unit Penjualan (Kg) & 40.943 & 40.943 \\
\hline $\begin{array}{l}\text { Unit Cost (harga } \\
\text { pokok) }\end{array}$ & Rp2.254 & Rp1.888 \\
\hline
\end{tabular}

Sumber:Diolah dari Laporan Keuangan BUMDes Amarta dan 2017

Berdasarkan tabel di atas perhitungan full costing menunjukkan harga jual yang lebih tinggi daripada perhitungan saat ini atau harga jual saat ini karena biaya-biaya yang digunakan untuk melakukan perhitungan tersebut dibebankan ke biaya produksi berupa biaya bahan baku, biaya tenaga kerja langsung, biaya overhead tetap, dan biaya overhead variabel. Berikut perbandingan harga jual BUMDes Amarta dengan menggunakan perhitungan costing. 
Tabel 2

Perbandingan Harga Jual dengan Metode Costing

\begin{tabular}{|l|c|}
\hline \multicolumn{1}{|c|}{ Keterangan } & Harga Jual \\
\hline Harga jual saat ini & Rp1.000 \\
\hline Harga pokok dengan Full Costing & Rp2.254 \\
\hline Harga pokok dengan Variable Costing & Rp1.888 \\
\hline
\end{tabular}

Berdasarkan tabel di atas, terlihat perhitungan dengan metode full costing dan variable costing menunjukkan unit cost (harga pokok) yang akurat. Harga jual yang didasarkan dengan metode tersebut dapat membantu BUMDes Amarta untuk mempertimbangkan kembali harga jualnya dan mempermudah dalam pengambilan keputusan berdasarkan harga pupuk yang ada di pasar dan pesaing.

Hasil analisis perhitungan full costing dan variable costing membantu untuk menjawab pertanyaan pertama penelitian ini bahwa BUMDes Amarta bisa menggunakan kedua metode tersebut. Akan tetapi, peneliti menyarankan untuk menggunakan perhitungan variable costing karena ketersediaan data yang didapatkan dan BUMDes Amarta dapat mempertimbangkan kembali harga jual pupuk organik tersebut. Berikut ini adalah hasil perbandingan harga jual pupuk dengan menggunakan metode perhitungan full costing dan variable costing.

Tabel 3

Perbandingan Laba atau Rugi Usaha dengan Metode Costing

\begin{tabular}{|c|c|c|}
\hline \multirow{2}{*}{ Tahun } & \multicolumn{2}{|c|}{ Rugi Usaha } \\
\cline { 2 - 3 } & Full Costing & Variabel Costing \\
\hline 2017 & Rp-51.342.522 & Rp-36.357.384 \\
\hline
\end{tabular}

Berdasarkan tabel di atas menjelaskan bahwa dengan adanya metode perhitungan full costing dan variabel costing tersebut, harga jual yang saat ini ditetapkan sangat rendah dan BUMDes Amarta mengalami kerugian sebesar Rp1.254,00 pada perhitungan full costing. Pada perhitungan variable costing mengalami kerugian sebesar Rp888,00. Meskipun laba/rugi bersih usaha pada tahun 2017 mengalami defisit karena laba/rugi tersebut menunjukkan laba/rugi operasional BUMDes Amarta. Dengan adanya pendapatan lain-lain, seperti pendapatan iuran warga yang membayar sampahnya ke BUMDes Amarta dan 
ada pendapatan dari luar usaha, seperti adanya kunjungan dari instansi-intansi dan lain-lain BUMDes Amarta mendapatkan laba. Akan tetapi, harga jual yang sudah ditentukan berdasarkan metode full costing dan variabel costing itu hanya menentukan batas bawah dan batas atas untuk menetapkan harga jual saat ini karena dengan harga $\mathrm{Rp} 1.000,00 / \mathrm{kg}$ BUMDes Amarta tetap menghasilkan laba.

Kalau saya yang penting bisa memberikan gambaran dan metode tersebut tidak sulit diterapkan. Bagi saya sebagai Direktur BUMDes, hal ini bisa memberikan gambaran bagaimana operasional perusahaan ini apakah sehat atau tidak sehat, apakah untung atau tidak untung dan ketika menjual produk itu sudah harga riilnya tidak hanya berdasarkan karangan atau intuisi bisnis saja tetapi memang itu hitungan yang sebenarnya dan bisa menunjukkan gambaran bahwa kami memproduksi pupuk dijual dengan harga sekian. Perhitungan dengan metode tradisional kami tidak rugi bagi kami sudah senang. Kami menyadari sumber manusia untuk BUMDes belum bagus dan belum mempunyai standar. Belum bisa memberikan penghasilan yang besar bagi pengelolanya, (AS1-17, Direktur BUMDes Amarta).

Berdasarkan hasil wawancara penelitian yang dilakukan, dapat disimpulkan bahwa perhitungan traditional costing ini sangat bermanfaat bagi BUMDes Amarta karena sebelumnya BUMDes Amarta pernah meminta kepada IRE (Institute for Research and Empowerment) untuk menghitung berapa unit cost/harga pokok yang bisa ditetapkan. Akan tetapi, IRE belum bisa melakukan perhitungan tersebut. Bagi BUMDes Amarta asalkan metode perhitungan costing tidak sulit untuk diterapkan dan bisa memberikan gambaran bagi operasional perusahaan. Di dalam laporan keuangan BUMDes Amarta tahun 2017 terdapat beberapa kesalahan pencatatan transaksi dan penempatan akun-akun keuangan. Gambar 1 dan 2 berikut ini menunjukkan triangulasi sumber dan triangulasi teknik mengenai analisis perhitungan costing di BUMDes Amarta. 


\section{Triangulasi Sumber}

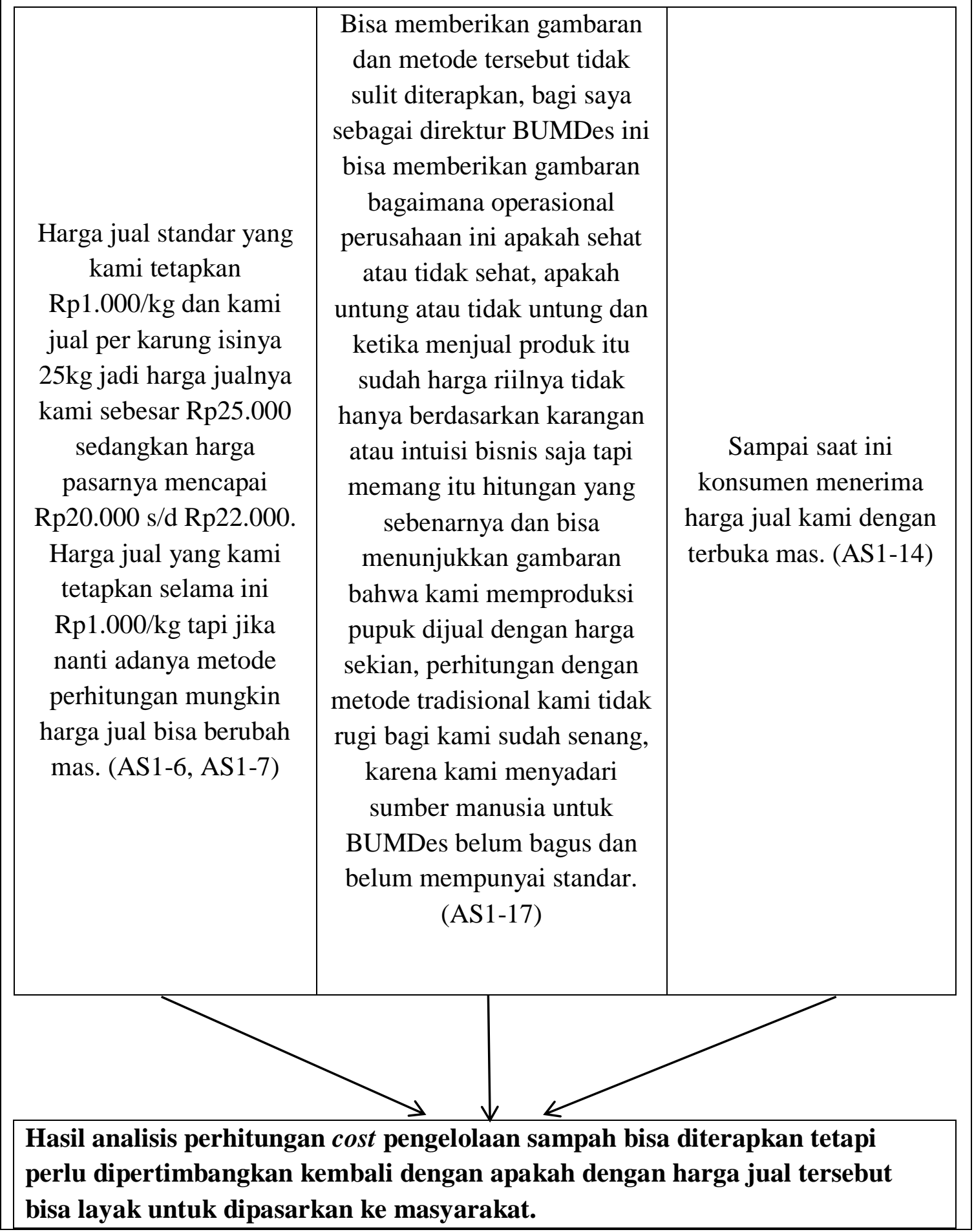




\section{Triangulasi Teknik}

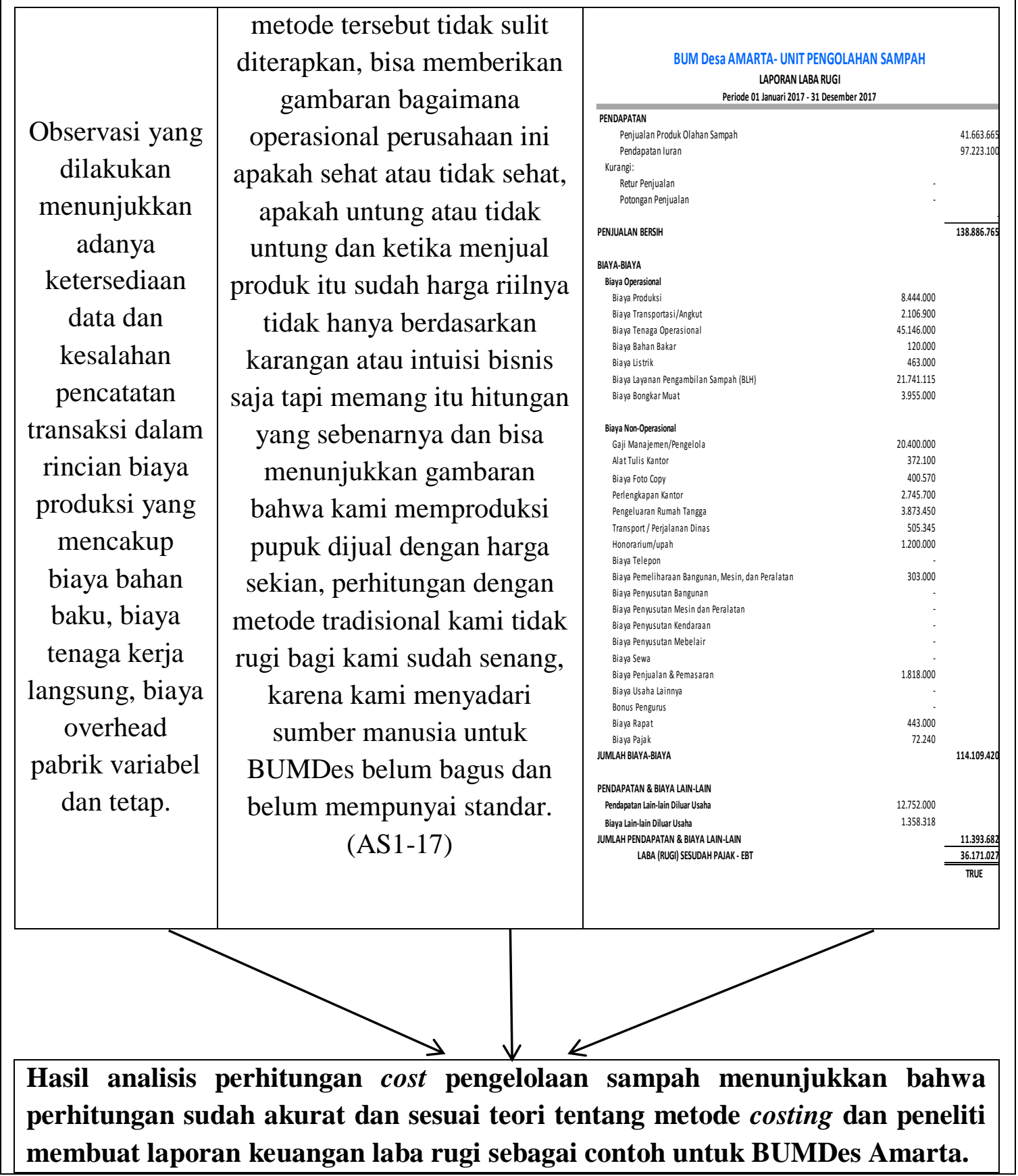

Gambar 2 Triangulasi Teknik Analisis Perhitungan Costing 


\section{Analisis Kelemahan Perhitungan Traditional Costing}

Pada sub bab ini peneliti menganalisis faktor-faktor yang menjadi kelemahan dalam perhitungan cost pengelolaan sampah tersebut. BUMDes Amarta memiliki beberapa kelemahan di dalam laporan keuangannya walaupun bisa dikatakan sehat dan transparan. Akan tetapi, ada beberapa akun-akun keuangan yang seharusnya tidak disajikan jika belum terdapat nominalnya.

Belum Mas, karena masih mau ditanyakan ke IRE berapa persen perhitungannya. Aset itu kita peroleh tidak hanya 1 bulan termasuk bangunan. Jadi belum ada perhitungan untuk biaya penyusutan tersebut dan masih dikonsultasikan ke IRE. Dengan harga sampah yang didapatkan secara gratis, jadi belum bisa untuk menentukan harga pupuk per kilogramnya, (PS4-4, Bendahara BUMDes Amarta)

Dulu itu sumber dananya sedikit, dan dari hasil iuran pelanggan saja kurang. Untuk biaya operasionalnya kadang cukup, kadang tidak. Jadi pernah punya hutang sebesar Rp7.000.000,00. Jadi, dulu upah itu tidak menentu. Dari iuran yang masuk berapa, kita keluarkan untuk biaya operasional berapa dan sisanya kita bagikan ke tenaga kerja. Bahkan, pengurus sama sekali tidak dapat dan malah tombok. Belum pernah saya mendapat surplus. Setelah diambil BUMDes sedikit demi sedikit mulai ada peningkatan. Dari desa juga belum ada campur tangan. Saya juga buat laporan keuangan ini tidak dapat respon apa-apa, (PS4-7, Bendahara BUMDes Amarta).

Berdasarkan hasil wawancara penelitian yang dilakukan, dapat disimpulkan

bahwa faktor-faktor yang menjadi kelemahan ialah biaya penyusutan belum dapat diakomodasi. Sampah didapatkan secara gratis sehingga belum bisa menentukan harga jualnya. Sumber dana terbatas dan pembuatan laporan keuangan yang dilakukan bendahara BUMDes Amarta tidak mendapatkan respon. Setelah ditangani IRE (Institute Research and Empowerment) baru mendapatkan respon dari pemerintah desa. Gambar 3 ini menggambarkan triangulasi sumber mengenai kelemahan-kelemahan yang ada pada perhitungan cost pengelolaan sampah. 


\section{Triangulasi Sumber}

Belum mas, karena masih mau ditanyakan ke IRE berapa persen perhitungannya. Jadi belum ada perhitungan untuk biaya penyusutan tersebut dan masih dikonsultasikan ke IRE. Dengan harga sampah yang didapatkan secara gratis, jadi belum bisa untuk menentukan harga pupuk perkilonya. (PS44)
Dulu itu sumber dananya sedikit, dan dari hasil iuran pelanggan saja kurang. Untuk biaya operasionalnya kadang cukup kadang tidak. Saya juga buat laporan keuangan ini tidak dapat respon apa-apa. (PS4-7)
Kalau penjabaran masalah pasti selalu ada dan bisa diselesaikan mas. Saya pesankan ke mba sekar yang membantu pak nur dalam pengelolaan keuangan. Jadi setiap ada mutasi itu dicatat, karena nanti dari bahan itu bisa diolah menjadi laporan seperti daftar kas harian yang bisa membantu untuk mengingatkan kita terjadinya mutasi-mutasi jika ada. (PS4-8)

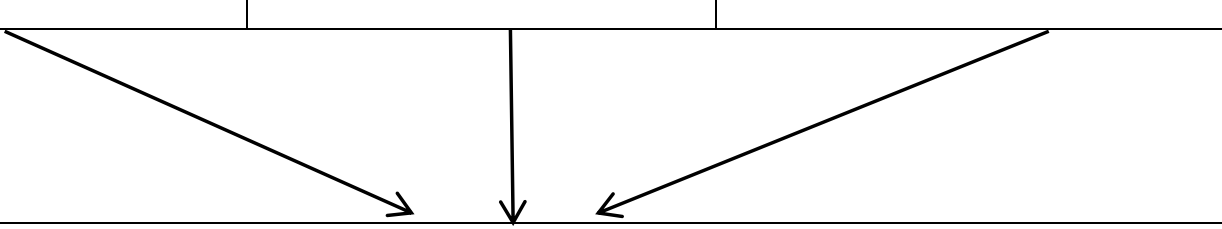

Faktor-faktor yang menjadi kelemahan yaitu belum mendapatkan perhitungan untuk biaya penyusutan, sampah didapatkan secara gratis sehingga belum bisa menentukan harga jualnya.

\section{Gambar 3Triangulasi Sumber Kelemahan Perhitungan Cost Pengelolaan Sampah}

\section{Perhitungan Cost Pengelolaan Sampah Yang Baik}

Alternatif terhadap perhitungan ini adalah dengan menerapakan perhitungan variable costing yang sudah dilakukan oleh peneliti. Dengan melihat kondisi laporan keuangan BUMDes Amarta, maka metode ini bisa diterapkan untuk mewujudkan visi misi Desa Pandowoharjo. Sebelumnya BUMDes Amarta tidak memiliki metode tersebut sehingga harga jual yang digunakan dengan melihat dari harga pasar. Walaupun dengan harga jual sekarang BUMDes Amarta mendapatkan keuntungan yang besar dan menjadi Desa yang berkembang saat ini, tetapi dengan menerapkan metode ini BUMDes Amarta bisa memaksimalkan profit dan benefit bagi internal maupun eksternal. 
Berdasarkan hasil wawancara mendalam, BUMDes Amarta dapat menerapkan perhitungan cost pengelolaan sampah karena mudah diterapkan dan dapat memberikan gambaran baginya dan Desa Pandowoharjo. Berikut hasil wawancara yang dilakukan peneliti terkait harga jual sebelum diterapkannya metode perhitungan cost.

Belum ada. Jadi kita hanya memperkirakan saja. Kita belum menghitung secara detail. Artinya itu bahan-bahan produksi belum stabil. Belum bisa menghitung dari produksi, tenaga kerja dan lain-lain. Jadi, hanya perkiraan karena banyak bahan pupuk itu gratis dari Jejamuran. Pupuk itu dampak dari pengelolaan sampah. Memang kendalanya dari tenaga kerja dan idealnya dari pengelolaan 3R itu tetapi belum ada tenaga kerja sehingga terbentuknya BUMDes yang mendapat respon dari warga sekitar. Jadi harga itu belum begitu besar karena itu masih dampak dan belum secara khusus untuk pupuk organik, (PS4-3, Bendahara BUMDes Amarta).

Berdasarkan uraian di atas, dapat disimpulkan bahwa sebelumnya BUMDes Amarta hanya memperkirakan saja harga jual pupuk dan belum ada perhitungan secara detail, dikarenakan bahan pupuk didapatkan secara gratis dari Rumah Makan Jejamuran. Harga jual pupuk organik sebelumnya lebih rendah dari harga pokok produksi. Ketidaktepatan harga jual akan mempengaruhi penentuan harga jual produk BUMDes Amarta yang lain. Metode perhitungan product costing yang sistematis dan akurat dapat memudahkan BUMDes Amarta untuk menghitung cost pengelolaan sampah yang mencakup hasil produksi pupuk organik, anorganik, dan pupuk cair.

\section{KESIMPULAN DAN SARAN}

\section{Kesimpulan}

Berdasarkan hasil penelitian yang telah dilakukan, dapat ditarik kesimpulan bahwa analisis perhitungan harga jual pupuk yang saat ini diterapkan oleh BUMDes Amarta masih kurang akurat karena belum didasarkan pada perhitungan product costing. 
Hasil analisis perbandingan perhitungan cost pengelolaan sampah yang telah dilakukan menunjukkan adanya faktor-faktor kelemahan terhadap perhitungan cost tersebut. Pertama, harga jual pupuk saat ini yang diterapkan oleh BUMDes Amarta masih terlalu rendah karena belum menggunakan metode costing. Kedua, biaya penyusutan belum diakomodasi dalam laporan keuangan sehingga BUMDes Amarta harus siap mengantisipasi aset BUMDes jika mengalami kerusakan agar proses produksi tidak terhenti dengan cara melakukan menyusun program peremajaan aset.

Dari kelemahan-kelemahan tersebut, alternatif perhitungan product cost yang lebih baik untuk menghasilkan harga jual yang efektif ialah dengan menggunakan metode variable costing. Hasil penentuan cost dengan metode tersebut lebih informatif daripada perhitungan saat ini yang dilakukan oleh BUMDes Amarta karena perhitungan product cost dengan variable costing menunjukkan unit cost (harga pokok) yang sesungguhnya. Selain itu, metode variable costing lebih sederhana, mudah diterapkan, dan komponen perhitungan sudah tersedia.Akan tetapi, perhitungan variable costing belum memperhitungkan biaya penyusutan aset tetap. Selain itu, perhitungan full costing menghasilkan cost yang terlalu tinggi dibanding pesaing-pesaingnya dengan harga rata-rata pupuk organik padat sebesar Rp1.500,00/kg (www.hargabarangterbaru.top/harga-pupuk-organik).

Untuk kedepannya BUMDes Amarta perlu menyajikan laporan keuangan yang lengkap dan mencakup biaya penyusutan mesin, gedung, dan peralatan agar perhitungan costing tersebut lebih akurat dan informatif sebagai dasar pengelolaan keuangan BUMDes Amarta yang komprehensif.

\section{Saran}

Berdasarkan penelitian yang telah dilakukan, peneliti memberikan saran kepada BUMDes Amarta sebagai berikut.

1. BUMDes Amarta dapat menggunakan metode variable costing sebagai metode perhitungan product cost karena metode tersebut mudah untuk diterapkan dalam BUMDes Amarta memberikan kemudahan informasi 
mengenai biaya-biaya sesuai dengan perilaku yang dibutuhkan sebagai dasar penentuan kos.

2. Berdasarkan pada perhitungan product cost melalui variable costing, BUMDes Amarta disarankan untuk mempertimbangkan kembali harga jual pupuk saat ini sebesar Rp1.000,00/kg. Saran dari peneliti ialah BUMDes Amarta bisa menjual pupuk seharga Rp1.500,00/kg berdasarkan survei yang telah dilakukan dengan info harga pupuk organik di pasar dan akses pasar, sehingga BUMDes memberikan subsidi sebesar 300/kg pupuk yang terjual. Subsidi tersebut berasal dari pendapatan iuran sampah yang telah dibayarkan oleh warga masyarakat Pandowoharjo.

3. BUMDes Amarta dapat melengkapi akun-akun keuangan yang belum lengkap, seperti biaya penyusutan mesin, gedung, peralatan, dan lain-lain supaya perhitungan product cost lebih komprehensif dan pengelolaan keuangan dapat lebih optimal.

4. Kelebihan kas yang dimiliki oleh BUMDes Amarta harus dicadangkan untuk mengantisipasi perbaikan/peremajaan aset.

Adapun saran untuk penelitian selanjutnya ialah meninjau kembali perhitungan product costing atau menambahkan metode perhitungan yang lain dalam penelitian ini dan bisa dilihat dari perkembangan produk BUMDes Amarta. Jika produk telah terdiversifikasi, BUMDes Amarta perlu menggunakan metode activity based costing. Hal ini didasarkan pada ragam produk pupuk yang dihasilkan oleh BUMDes Amarta.

\section{DAFTAR PUSTAKA}

BBLM Yogyakarta. Balai Besar Latihan Masyarakat. 2016. Kunjungan Ke BUMDes Amarta, Pandowoharjo Sleman. Diambil dari: Http://bblm_yogyakarta.kemendesa.go.id/index.php/view/detil/156/kunjun gan-ke-bumdes-amarta-pandowoharjo-sleman.

Carter, William K. 2009. Akuntansi Biaya Edisi 14. Terjemahan Krista. Jakarta: Salemba Empat. 
Creswell, J.W. 2014. Research Design: Qualitative, Quantitative, and Mixed Methods Approaches, $4^{\text {th }}$ edition. California: SAGE Publication.

Cresswell, John. W. 2015. Penelitian Kualitatif \& Desain Riset. Yogyakarta: Pustaka Pelajar.

Cresswell, John. W. 2016. Research Design: Pendekatan Metode Kualitatif, Kuantitatif, dan Campuran. Edisi 4. Yogyakarta: Pustaka Pelajar.

Garrison dan Norren. 2010. Akuntansi Manajerial. Salemba Empat, Jakarta.

Hansen, Don R dan Maryane M, Mowen. 2006. Akuntansi Manajemen, Edisi 7. Salemba Empat: Jakarta.

Hayyuna, Rizka. Et al. 2012. Strategi Manajemen Aset Bumdes Dalam Rangka Meningkatkan Pendapatan Desa. Jurnal Administrasi Publik (JAP), Vol. 2, No. 1 , Hlm. $1-5$.

Horngren, Charles T., Datar, Srikant M., dan Foster, George. 2008. Akuntansi Biaya, Edisi Kedua Belas Jilid 1. Jakarta: Erlangga.

Kartikasari, Dian W. 2010. Analisa Biaya Satuan Layanan Perpustakaan Umum Daerah Studi Kasus: Kantor Perpustakaan dan Arsip Jakarta Pusat. Tesis.

Khairunnisa, Anita. 2015. Analisis Perbandingan Metode Tradisional dan Metode Activity Based Costing dalam Perhitungan Unit Cost pada PD Kebersihan Kota Bandung. Universitas Pendidikan Indonesia. Skripsi.

Miles, Matthew. B, Huberman, A. Michael, Johny Saldana. 2014. Qualitative Data Analysis $3^{\text {rd }}$ edition. USA: SAGE Publications.

Mulyadi. 1993. Akuntansi Biaya, Yogyakarta: STIE YKPN.

Mulyadi. 2005. Akuntansi Biaya, Edisi 5. Yogyakarta: UPP STIM YKPN.

Mulyaning. 2003. Analisis Harga Pokok Produk dengan Metode Activity Based Costing pada Pabrik Spiritus Madubaru PT. Madukismo Yogyakarta. Universitas Gadjah Mada. Tesis.

Novyanti, Mita. 2013. Dampak Program Bank Sampah Terhadap Sosial Ekonomi Masyarakat Di Kelurahan Binjai, Kecamatan Medan Denai. Universitas Sumatera Utara. Jurnal Ekonomi Kuantitatif Terapan. Vol. 9, No. 1, Februari 2016. 
Tim Pengkaji dan Perumus BUMDes. 2016. Laporan Hasil Kajian dan Perumusan Pembentukan Badan Usaha Milik Desa (BUMDes). Desa Pandowoharjo, Sleman, Daerah Istimewa Yogyakarta.

Undang-Undang No 6 Tahun 2014 tentang Peraturan Desa.

Peraturan Menteri Dalam Negeri Nomor 39 Tahun 2010 tentang Badan Usaha Milik Desa. 25 Juni 2010. Negara Republik Tahun 2010 Nomor 316. Jakarta.

Peraturan-Peraturan No. 72 Tahun 2005 tentang Desa.

Purwolastono, Agus Dwi. 2013. Analisis Biaya Pendidikan dengan Pendekatan Activity Based Costing System: Studi Kasus pada Jurusan Elektro, Fakultas Teknologi Industri Institut Teknologi Sepuluh November Surabaya. Universitas Gadjah Mada. Tesis.

Putuhena, Hempry. 2015. Perbandingan Penerapan Akuntansi Biaya Tradisional, Activity Based Costing dan Time Driven Activity Based Costing. Universitas Gadjah Mada. Tesis.

Sudarmaji, Agus. 2000. Analisis Penarifan Retribusi Pelayanan Persampahan/Kebersihan dengan Metode Activity Based Costing (Studi di Kota Semarang). Universitas Diponegoro. Tesis.

Sutanto, Lina. 2001. Penerapan Activity Based Costing pada Rumah Sakit Panti Rapih Yogyakarta. Universitas Gadjah Mada. Tesis.

Sugiyono. 2016. Metode Penelitian Kuantitatif, Kualitatif, dan R\&D. Bandung: Alfabeta.

Supriyono, RA. 1999. Manajemen Biaya Suatu Reformasi Pengelolaan Bisnis. Jilid 1. Yogyakarta: BPFE.

Supriyono. 2007. Manajemen Biaya Suatu Reformasi Pengelolaan Bisnis. Yogyakarta: BPFE.

Suwardjono. 2014. Teori Akuntansi Perekayasaan Pelaporan Keuangan. Edisi Ketiga. Yogyakarta: BPFE.

Yin, R.K., 2014. Case Study Research, Design and Methods, 5th ed. California: SAGE Publications. 